TURIZAM

Volume 23, Issue 3

145-156 (2019)

ORIGINAL

SCIENTIFIC PAPER

\title{
Environmentally Sustainable Tourism as a Strategic Determinant of Economic and Social Development
}

\author{
Dijana Vuković $\mathrm{A}^{*}$, Anica Hunjet ${ }^{\mathrm{A}}$, Goran Kozina ${ }^{\mathrm{A}}$ \\ Received: April 2019 | Accepted: September 2019 \\ DOI: 10.5937/turizam23-21135
}

\begin{abstract}
Tourism as an activity can make a positive contribution to social and economic development, but, at the same time, with its fast and uncontrolled growth it may cause substantial damage to ecological values and loss of local identity and traditional cultural values. The protection of biological, spatial and cultural values is imperative for sustainable tourist destinations to attract consumers. In a tourism analysis, natural attractions and the environment of a tourist destination are vital components of development. When choosing a travel destination, the consumer's perspective affects the comparative advantage of the destination on the global tourism market, its reputation, its potential to attract and retain tourists, the quality of life and the standard of living of local residents, as well as potential investments. The paper aims to examine the environmental component as a strategic determinant of the development of a tourist destination. The paper investigates the many factors affecting the decisions of the management of a destination and looks in more detail at the pressures put by tourism activities on the eco-systems of travel destinations, which accelerate and intensify the consumption of destination values.
\end{abstract}

Keywords: sustainable development in tourism, environmental sustainability, tourist destination, concept of resource use indicators, responsibility of tourist destination

\section{Introduction}

Tourism, as a service sector activity and one of the drivers of economic growth and development of a tourism-oriented country, is facing numerous 21st century challenges. It has become imperative for sustainable tourist destinations to involve a variety of business entities and use various types of cooperation in the planning of their activities so that they can gain a competitive advantage on the tourism market. Regardless of its size, a sustainable tourist destination must ensure its sustainable development, offer authenticity, provide adequate infrastructure, protect natural and anthropogenic destination values, and ensure efficiency of business entities in order to gain a distinctive advantage over its many competitors. Given that tour-

\footnotetext{
A University North, Jurja Križanića 31b; 42000 Varaždin, Croatia

* Corresponding author: dijana.vukovic@unin.hr
} 
ism development can place a considerable strain on local resources and cause environmental harm, in order to achieve sustainable development, there is a need to find a balance between the responsibility for environmental protection and tourist destination development. The ecological effectiveness of a tourist destination implies the undertaking of certain activities to achieve environmental goals, while environmental efficiency implies actions taken by a sustainable tourist destination in order to achieve an efficient and environmentally-balanced sustainable development.

The best way to create environmental balance is through the use of environmental balance indicators, which show the level of natural resource use, the state of natural resources, and the role of natural resources in the preservation and enhancement of the quality of the environment and living conditions. Tourism marketing is always focused on the expectations and needs of tourists. The destination management, on the other hand, faces a challenge of how to protect natural resources, achieve environmental integrity recognizable on the global tourism market, avoid overstretching nature's capacities, operate cost-effectively, and meet the needs of tourists. The paper aims to define the basic factors of sustainability, which are based on the principles of the landscape approach. Moreover, the research points to the necessity of implementing the sustainable development concept, which is supposed to enhance positive synergies between the living environment, protecting sociocultural traditions, meeting the needs of tourists and making a profit while striving to minimize negative effects.

\section{Socially responsible strategies at the tourist destination level}

The concept of resource use indicators is of particular importance in tourism given that sustainable development of tourist destinations involves managing development goals and resource use with the aim of successfully transforming available inputs into tourist traffic. The tourism sector is unique in that it depends on intact ecosystems, while at the same time it puts considerable pressure on them. Hence, it may be concluded that sustainable tourist destinations require special resource management techniques. Tourist destinations shape their own sustainability policy, decide on resource management practices, and develop a sustainability culture and sustainability strategy with a view to successfully responding to the challenges of resource management. The implementation of sustainability in the strategic plans of the destination is challenging, not only in terms of designing the model, but also in terms of monitoring and measuring resource use indicators.

A sustainable tourist destination strategy is oriented towards efficient management of the environment and resources for the purpose of gaining a comparative advantage (Hart, 1995) by taking into account non-market value in the form of continuous cooperation with local communities, legislators and corporate entities (Atkinson, 2000: 235-252). Such an approach to strategy development has several practical shortcomings, mostly in terms of measuring the performance, and confusion resulting from the threefold goal. There is no clear consensus about the formulation of environmental and social goals, and even when they have been defined, there is disagreement in the hierarchical ordering of goals because, as expected, the economic ones are usually given priority.

The use of natural resources in equipping tourism facilities is one of the most important indicators in creating and placing an integrated tourism product on the market. Major indicators also include the use of land for the construction of accommodation facilities, development of infrastructure, choice of locations, and use of building materials. Deforestation and 
destructive use of land for the construction of tourism facilities and infrastructure cause land erosion and loss of biodiversity. Irresponsible behaviour and inadequate regulation of tourism activity (e.g. cycling in protected areas outside cycling routes, poaching, illegal fishing, illegal plant picking, diving using diving equipment) have a direct impact on the local wildlife. In addition, tourism consumers and means of transportation that they use can increase the risk of or cause dramatic changes in the behaviour of animals. Tourism-related construction activities can bring changes to the habitats of wild and protected animals.

The pressures that tourism puts on natural resources are enormous and include as follows: land erosion, pollution and environmental degradation due to the construction of sand pathways, tourist camps, apartments, hotels, etc. Tourism activities have a direct impact on the environment as a whole, its resources and their diversity. This occurs mostly as a result of inadequate planning, irresponsible behaviour of tourism consumers or other stakeholders. Sustainable tourism indicators show the potential for development of tourist destinations and are thus used to assess and select an adequate development process that will protect destination values. The use of indicators is based on the limit value coding system for each indicator. Based on sustainable development indicators, the state of a tourist destination can be assessed as:

- critical,

- tolerable,

- sustainable.

Resources at the destination level are temporary in nature. For this reason, sustainable tourist destinations must configure their resources at the beginning of each new season. A sustainable tourist destination can be defined as a complex system of organising and managing the resources and processes aimed at fulfilling the identified vision, mission and primary goals.

Sustainable tourist destinations are characterised by the following:

- $\quad$ sustainability is integrated into the destination value system,

- $\quad$ sustainability is the central part of the strategy based on which the destination is positioned in the market,

- a developed sustainability indicator monitoring system (metrics),

- holistic integration of sustainability into all functions of destination management,

- $\quad$ systemic coherence (sustainability in structures and processes),

- support to sustainability of an integrated tourism product provided by all stakeholders,

- involvement of stakeholders with interest in and influence over the tourist destination.

That is why the concept of resource indicator measurement at the tourist destination level is vital. It correlates development goals and resource use with the aim of successfully transforming available inputs, i.e. the resources used, into the value delivered to consumers. The transformation of resources into values takes place in a dynamic environment that changes with trends and consumer preferences.

These values enable a tourist destination to be sustainable, but they also entail risks and constraints. Changing market conditions require continuous adaptation in terms of the volume and structure of engaged resources and tourism sector employees, as well as adaptation of the functional features of the destination to new trends, and the redefining of values delivered to consumers. 
Table 1. Sustainability assessment based on indicators at the level of tourist destination

\begin{tabular}{|c|c|c|}
\hline & Indicator & Unit \\
\hline \multirow{3}{*}{ Economic } & Unemployment rate & $\%$ of total labour force \\
\hline & Seasonality of tourism activity & $\begin{array}{l}\text { Average number of visitors per season / } \\
\text { average number of visitors during the off- } \\
\text { season }\end{array}$ \\
\hline & Natural resources with eco-labels & $\begin{array}{c}\% \text { of resources with eco-labels in relation to } \\
\text { total destination values }\end{array}$ \\
\hline \multirow{2}{*}{ Social } & Poverty rate & $\%$ of population \\
\hline & Visits to cultural and natural heritage sites & Number of visits per annum \\
\hline \multirow{5}{*}{ Environmental } & Built-up areas & $\begin{array}{c}\% \text { increase compared to the reference tourist } \\
\text { year }\end{array}$ \\
\hline & Protected nature & $\begin{array}{c}\% \text { of the surface area of the tourist } \\
\text { destination } t / \mathrm{m} 3 / \text { year }\end{array}$ \\
\hline & $\begin{array}{l}\text { Waste collected on beaches and in public } \\
\text { areas }\end{array}$ & \\
\hline & Sanitation coverage & $\%$ of population with sewer connection \\
\hline & Bathing water quality & $\begin{array}{c}\% \text { of beaches with excellent bathing water } \\
\text { quality }\end{array}$ \\
\hline
\end{tabular}

Source: author's work

The concept of the resource measurement indicator at the level of tourist destination is important for the integrated management of the tourism product and therefore it needs to be defined when assessing destination sustainability. The use of resources at the tourist destination level is ensured by their mobilisation.

Costs and engaged resources are managed through the process of resource utilisation. The resource management process at the tourist destination level begins by determining the future resource consumption at the destination level and establishing optimal utilisation. Destination sustainability assessment is the fundamental concept of indicators for future resource measurement at the tourist destination level. It is presented in Table 1. Resources at the tourist destination level are temporary in nature, and that is why sustainable tourist destinations need to configure them at the beginning of each new tourist season. A sustainable tourist destination can be defined as a complex system of organizing and managing resources as well as processes aimed at fulfilling the set vision, mission and primary goals (Table 1).

The most comprehensive list of indicators in the scientific papers and publications that can be applied to Croatian tourist areas due to the similarities of geographical features was proposed by Farsari and Prastacos who used the Mediterranean destinations as an example (2000: 59, 2001: 103-121), while Coccossis and Mexa did the same at the level of the conceptual proposal (2004: 276).

\section{Environmental action models}

An environmental action model includes actions and measures aimed at protection, revitalisation, and optimal use of the destination and its tourism values. Such a model must be incorporated into development policies and strategies as well as specific planning and development documents. Unlike the strategies used in the past, the concept of sustainable tourism development gives priority to environmental action models, environmental measures, and environmental pol- 
icy goals of sustainable tourist destinations. The concept of sustainable development in tourism is analysed by means of sustainable functioning and sustainable systems theory. A model of environmental action in a sustainable tourist destination is based on the following elements:

- $\quad$ it is composed of independent elements;

- all elements of the model are interrelated;

- the model functions in accordance with the purpose and objectives of sustainability;

- the model of environmental action has limits;

- the model seeks to establish balance;

- the change in one element of sustainability causes indirect changes in other elements of sustainability due to their interrelationship.

The defining and implementing of environmental action is based on the set ISO standards and impacts the development of the concepts "total quality" and "green consumers" that have become increasingly important in the tourism sector as well. A large number of stakeholders involved in the creation of a sustainable tourism offer require the implementation of a high-quality management system that will take into account all the factors of sustainable development as well as the factors that the consumer perceives as values. The model of environmental action in a sustainable tourist destination has multiple positive impacts on the future development of that destination as well as the overall development of tourism. The model has to focus on two things.

First of all, it is a system, which means that it is a general and comprehensive concept. Furthermore, the management of a sustainable tourist destination must bear in mind that this model affects the level of consumer satisfaction and expectations and must provide for the implementation of environmental measures in their destination in the future. In particular, the model requires high accuracy and consistency, and has to take into consideration the fact that there are difficulties in controlling environmental action, mainly created by the consumer.

The model of environmental action is based on the following fundamental assumptions (Ahlheim, Lehr, 200o):

- First and foremost, the outcomes and goals that are to be achieved by the model need to be precisely identified;

- Next, it is necessary to determine the features of the required elements of environmental action;

- Finally, it is necessary to make a well-thought-out decision about the nature and the type of relationship that must be established between the various stakeholders in a sustainable tourist destination in order to achieve environmental action goals.

Environmental action models are aimed at ensuring long-term protection and conservation of natural, cultural and social resources and enhancing the quality of domestic tourist destinations, as well as the quality of life of the local population and of the services provided to tourism consumers. Sustainable tourist destinations promoting the model of environmental action (according to Ahlheim, Lehr, 20oo:145-146):

- $\quad$ strive to minimise the impact of tourism activities on climate change;

- implement energy efficiency measures in the construction (e.g. by conversion of abandoned or vacant land and buildings in sustainable tourist destinations), equipping of the facilities (e.g. touch lighting, minimisation of drinking water consumption, energy efficient washing machines, special showers), and energy supply (renewable energy sources - wind power plants, solar energy); 
- $\quad$ establish an integrated waste management system;

- $\quad$ introduce recycling and reuse practices;

- continuously educate local employees, their families, young people, and children on the need and ways to protect the environment;

- $\quad$ expand the tourism offer to locally sourced, sustainable foods produced according to the principles of organic agriculture;

- encourage the use of public transport; provide visitors with transport from the airport/ harbour/railway station to the hotel and back.

\section{The integrity and uniqueness of natural features as part of natural resource management in a sustainable tourist destination}

The integrity and uniqueness of natural features as a destination resource can be described as a list of elements of all natural beauties found in a particular destination area. It is the cornerstone or the core of the tourism product of that destination. It no longer involves mere mapping of clustered or scattered natural attractions or describing how they differ from those in other destinations, but analysing the dynamics created by the physical presence of various elements of natural heritage. The integrity and uniqueness of natural features represent the destination value that includes the key elements of tourist demand.

The term hardware can be used to refer to the tourism infrastructure, the characteristics of an area, the immovable heritage, the morphology and architecture of the developed environment, and deeply rooted cultural resources. In many cases, the term hardware also includes key elements of the spectrum of tourism potential. As a rule, these elements of tourist attractions are not easily relocated and, by their definition, represent great expense to interested parties in terms of their protection and maintenance. Managing natural features and the environment as heritage destinations is a relatively new paradigm in Croatia. As any other new model, it is still being developed. However, it is interesting to note that in all jurisdictions it evolves through a five-stage process. The process starts with the identification of the natural feature and the level of their preservation as a destination value. Next, the political interest increases and then the level of professionalism advances. With the development, it is expected that new phases will be identified, but the existing ones include:

1. the initial and continuous inventory,

2. provision of basic legal protection,

3. the stage of growing professionalism,

4. consultations and stakeholder participation, and

5. the phase of reviewing professional and government responsibility.

In order to better understand the concept of management of a natural heritage destination, it is necessary to understand the content and meaning of individual concepts, such as natural features and biodiversity, i.e. the core environmental values of a sustainable tourist destination. Naturally, as any other organised activity, the conservation of protected natural values of destinations is carried out according to defined principles.

The process comprises five stages. It begins with identifying the value of natural features and recognizing the need for their conservation and protection. The first phase typically involves beginning attempts at documentation of natural values, often by enthusiastic amateurs or destination lovers. Gathering information on the natural values of a destination helps to better 
understand the value of natural features. This information is stored on different media and can be found in the archives of many institutions. It should be entered in the register of natural heritage at the level of the tourist destination, which contains the list of protected natural heritage, natural heritage of national significance and preventively protected natural heritage. Once the scope of natural heritage is established under the legal jurisdiction and in agreement with the Act on the Protection of Natural Heritage, the next step is taken. This phase involves the adoption of a regulation aimed at recognizing and conserving these natural resources and may also include cataloguing and further involvement of enthusiasts. Problems are likely to arise when there is no clearly defined plan for resolving potential conflicts regarding their use.

The protection of natural values, i.e. natural heritage, of a sustainable tourist destination is often very complex and professionally challenging. Therefore, in order to maintain and protect environmental integrity, many situations can only be solved through the cooperation of all stakeholders and active participation of the destination management. However, this does not mean that the responsibility for the protection of natural values rests solely on government institutions that are the paid experts to do the work. Natural heritage is the concern and responsibility of all stakeholders in tourism. Ritchie and Crouch (2003) claim that public sector stakeholders are responsible for developing policies of tourist destinations, whose aim must be to create an environment that maximises the benefits for other stakeholders while minimizing negative impacts. According to Komppuli (2014), municipalities and cities have the most important role in the development of a destination, because strategic decisions (spatial planning documents and land use) and investments in public infrastructure create opportunities for entrepreneurs to develop their business activities.

The responsibility also lies with destination management organisations, whose primary role should be to coordinate the interests and activities of public and private stakeholders in tourism. This suggests that it is necessary to manage environmental integrity on natural heritage sites. This implies:

- a multidisciplinary approach and performing an economic, environmental and socio-cultural analysis;

- continuous cooperation with key stakeholders - consultations and workshops with entrepreneurs, public administration, family farms, local self-government units, tourist boards, system for nature protection, system for cultural activities, etc.;

- $\quad$ public access to development programmes and strategies -organizing public discussions, using means of public information, having two-way communication between institutions responsible for strategic development and the local community;

- The development of a strategy does not end with its design. This is a long-term project that needs to be flexible and ready for changes due to constant changes in the environment. It involves a steady dialogue and network partnership between entrepreneurs, the public sector and the interest sector for the protection of nature and cultural heritage.

\section{Research methodology}

An integrated approach to the protection of natural heritage in tourist destinations requires finding a balance between the interests and investment projects of the public and private sector and those of local population. In this context, several questions need to be answered. What are direct and indirect benefits of natural heritage protection for the local community? What is the local population's perception of the importance of protecting natural heritage? What is 
their opinion on the development of special forms of tourism and new tourist products in their surroundings with regard to the natural destination values? Does the local population feel the need to be involved in the protection of natural heritage? Also, the opinions of active stakeholders in tourism concerning mutual cooperation and partnership within their local communities are still unknown. Therefore, the present research established the stakeholders' perceptions of other stakeholders at the destination level as well as their views regarding mutual responsibility for the protection of natural heritage.

The research is focused on three key elements: entrepreneurial sustainability, place and environment conservation and the positive attitude of the local population towards expansive tourism development. The research topic, its aims and hypotheses determine the type of sampling, which is deliberate, but obtained by random choice. All stakeholders in the private and public sectors are essential for tourism development because they take on an active role in developing an integrated tourism product and its protection. The research results indicate the necessity for a partnership cooperation in the creation of a tourism product as a recognizable destination brand and raising the competitiveness in tourism.

This research on environmental sustainability of tourism as a strategic guideline is based on the assumption that tourism is a powerful tool for the economic development of a destination. An integrated approach to the development of tourism activity is a prerequisite for the sustainable tourism development of a destination. The integrated approach implies close involvement of local communities and partnership of all stakeholders, as well as systematic tourism development planning.

The key stakeholders in this process are the public sector (local and regional self-government, tourist boards, city and county institutions and companies, relevant ministries), the private sector (hoteliers, private accommodation owners, the catering industry, farmers and small businesses) and the civil sector (local action groups, civil associations, local initiatives). In order to set the guidelines for future integrated development of the destination area, this paper aims to investigate the local population's perspective regarding the need for environmental integrity management and the local stakeholders' perspective of each other and their mutual responsibility in the development of tourism. Hence, the following three research hypotheses are proposed:

H1: The protection of natural heritage and environmental integrity of natural resources implies use of tourism destination that minimises negative impacts on nature and the local population;

H2: The primary goal of destination management is the protection of natural heritage with the purpose of delivering an integrated tourist product;

H3: Protection of natural resources affects long-term participation of the local population in decision-making.

A survey was carried out among local residents of Plitvice Lakes, the island of Rab and the island of Krk. The sample comprised 352 respondents. Structured interviews were used in the survey. 
Table 2. The correlation of sample demographics with the respondents' opinions on the need for protection of natural heritage

\begin{tabular}{|c|c|c|c|c|c|}
\hline & & $\begin{array}{l}\text { Respondents' opinion } \\
\text { about the need for } \\
\text { protection of natural } \\
\text { heritage }\end{array}$ & $\begin{array}{l}\text { Age of } \\
\text { respondents }\end{array}$ & $\begin{array}{l}\text { Level of } \\
\text { education }\end{array}$ & $\begin{array}{c}\text { Employed in } \\
\text { tourism }\end{array}$ \\
\hline $\begin{array}{l}\text { Respondents' opinion } \\
\text { on the need for nature } \\
\text { protection }\end{array}$ & $\begin{array}{l}\text { Pearson Correlation } \\
\text { Sig.(2-tailed) } \\
\mathrm{N}\end{array}$ & $\begin{array}{c}1 \\
352 \\
\end{array}$ & $\begin{array}{r}-.016 \\
.765 \\
352\end{array}$ & $\begin{array}{l}.175^{* *} \\
.001 \\
352\end{array}$ & $\begin{array}{l}.003 \\
.954 \\
352\end{array}$ \\
\hline Age of respondents & $\begin{array}{l}\text { Pearson Correlation } \\
\text { Sig.(2-tailed) } \\
\mathrm{N}\end{array}$ & $\begin{array}{r}-.016 \\
.765 \\
352\end{array}$ & $\begin{array}{c}1 \\
352 \\
\end{array}$ & $\begin{array}{r}-.054 \\
.314 \\
352 \\
\end{array}$ & $\begin{array}{c}-0.049 \\
.360 \\
352\end{array}$ \\
\hline Level of education & $\begin{array}{l}\text { Pearson Correlation } \\
\text { Sig.(2-tailed) } \\
\mathrm{N}\end{array}$ & $\begin{array}{l}.175^{* *} \\
.001 \\
352\end{array}$ & $\begin{array}{l}-.054 \\
.314 \\
352\end{array}$ & $\begin{array}{c}1 \\
352\end{array}$ & $\begin{array}{l}.009 \\
.865 \\
352\end{array}$ \\
\hline Employed in tourism & $\begin{array}{l}\text { Pearson Correlation } \\
\text { Sig. (2-tailed) } \\
\text { N }\end{array}$ & $\begin{array}{l}.003 \\
.954 \\
352\end{array}$ & $\begin{array}{r}-.049 \\
.360 \\
352\end{array}$ & $\begin{array}{l}.009 \\
.865 \\
352\end{array}$ & $\begin{array}{c}1 \\
352\end{array}$ \\
\hline
\end{tabular}

**. Correlation is significant at the 0.01 level (2-tailed).

As is evident from Table 2, there is no statistically significant correlation of the respondents' age and employment in tourism with their opinion on the need for protection of natural heritage, regardless if their opinion was positive ("protection of natural heritage aimed at achieving environmental integrity is a precondition for the development of tourist activity in the destination") or negative ("protection of natural heritage aimed at achieving environmental integrity is not a precondition for the development of tourist activity in the destination").

However, a statistically significant positive correlation was found between the level of education and the respondents' opinions on the protection of natural heritage aimed at environmental integrity, although the coefficient of correlation is rather low $(\mathrm{r}=0.175, \mathrm{p}<0.01)$. Hence, it may be concluded that the level of education is positively correlated with the respondents' opinion "protection of natural heritage aimed at environmental integrity is a precondition for the development of tourist activity in the destination". As shown in Table 3, the Chi-square test shows statistically significant differences in the respondents' opinions about their role in the decision-making about tourist destination management.

Table 3. Chi-square test

\begin{tabular}{|c|c|}
\hline Statistical test & The role of local population in making decisions on destination management is significant \\
\hline Chi-square & $170.649 \mathrm{a}$ \\
\hline $\mathrm{df}$ & 4 \\
\hline Asymp. Sig. & .000 \\
\hline a. 0 cells (.0\%) have expected frequencies frequency less than 5. The minimum expected cell is 66.6. \\
\hline
\end{tabular}

Source: author's work

As is evident from Table 3, a considerably larger number of respondents than expected in normal distribution agree that their role in the decision-making on the destination management is small, which implies their disagreement with the proposed statement. More specifically, 120 respondents strongly disagree with the proposed statement, while 126 respondents disagree with it. 
The results obtained for the statement concerning the respondents' opinion about the need for protecting natural heritage and achieving environmental integrity are shown in Table 4.

Table 4. Opinion of local population on the need for protecting natural heritage and achieving environmental integrity as a precondition for delivering a high-quality integrated tourism product

\begin{tabular}{|c|c|c|c|c|c|c|c|c|c|c|c|c|}
\hline Average & \multicolumn{3}{|c|}{$\begin{array}{c}\text { Age of } \\
\text { respondents }\end{array}$} & \multicolumn{3}{|c|}{ Level of education } & \multicolumn{2}{|c|}{$\begin{array}{l}\text { Employed in } \\
\text { tourism }\end{array}$} & \multicolumn{4}{|c|}{ Area - Island of Rab } \\
\hline 4,02 & a) & b) & $c, d)$ & $\begin{array}{l}\text { Secondary } \\
\text { education }\end{array}$ & $\begin{array}{l}\text { 2-year post- } \\
\text { secondary education }\end{array}$ & $\begin{array}{l}\text { Higher } \\
\text { education }\end{array}$ & YES & NO & a) & b) & c) & d) \\
\hline & 4,01 & 4,07 & 3,91 & 3,91 & 3,99 & 4,17 & 4,11 & 3,98 & 4,23 & 3,87 & 4,05 & 4,36 \\
\hline
\end{tabular}

Source: author's work

The average score for this statement is 4.02, which suggests that the respondents are optimistic about their area becoming an attractive tourist destination in the future (previous question, average score - 3.24). When it comes to differences in the respondents' opinions depending on their place of residence, those coming from the island of Rab are more positive about the future prospects of their area - 4.23 (compared to the island of Krk - 3.87).

Table 5 shows all significant Chi-square test results indicating the differences in the respondents' opinions on the importance of valorisation of natural and cultural heritage as major factors in tourism development.

As is evident from Table 5, the majority of respondents $(\mathrm{N}=184$, expected $\mathrm{N}=58.7)$ agree that valorisation of natural heritage is a major factor in tourism development. Moreover, the majority of respondents $(\mathrm{N}=187$, expected $\mathrm{N}=58.7)$ agree that the valorisation of cultural heritage is a major factor in tourism development. As far as the valorisation of activity, sports and food tourism is concerned, the majority of respondents $(\mathrm{N}=17 \mathrm{O}$ and $\mathrm{N}=174)$ agree that they are important factors in the development of tourism.

Table 5. Hi square test

\begin{tabular}{|l|c|c|c|c|}
\hline Statistical test & $\begin{array}{c}\text { Valorisation of natural } \\
\text { heritage is one of the } \\
\text { main drivers of/factors } \\
\text { in tourism development }\end{array}$ & $\begin{array}{c}\text { Valorisation of cultural } \\
\text { heritage is one of the } \\
\text { main drivers of/factors } \\
\text { in tourism development }\end{array}$ & $\begin{array}{c}\text { Valorisation of active } \\
\text { vacation and sport } \\
\text { tourism is one of the } \\
\text { main drivers of/factors } \\
\text { in tourism development }\end{array}$ & $\begin{array}{c}\text { Valorisation of local } \\
\text { gastronomy is one of } \\
\text { the main drivers of/ } \\
\text { factors in tourism } \\
\text { development }\end{array}$ \\
\hline Chi-square & $378.227 a$ & $390.909 a$ & $351.739 a$ & $331.011 a$ \\
\hline df & 5 & 5 & 5 & 5 \\
\hline Asymp. Sig. & .000 & .000 & .000 & .000 \\
\hline
\end{tabular}

a. 0 cells (.0\%) have expected frequencies less than 5 . The minimum expected cell frequency is 58.7 .

\section{Conclusion}

Tourism development is highly dependent on the quality of life in the tourist destination, its natural and cultural values and features. Therefore, the attractiveness and the level of preservation of the destination's features are directly reflected in the development of tourism at the destination. This is especially true for selective forms of tourism, such as recreational tour- 
ism, agri-tourism and rural tourism. Expansive development of tourism today has shown that an uncontrolled approach to destination development has a negative impact on environmental integrity and preservation of natural heritage, just as much as uncontrolled development of industry and urbanisation.

Environmental integrity allows for valorisation of those elements of the destination which are of marginal interest to a variety of other activities, such as sand or shingle beaches, lakes and rivers, wetlands, snow-covered mountain slopes, as well as other elements such as climate, caves, and relict or endemic plants and animals.

Tourism makes use of the destination space; however, the use of natural resources by tourism is not irreversible. As a global phenomenon, tourism transforms the destination and alters its physiognomy by equipping, remodelling and restructuring it. For this transformation process to be successful, it is necessary to adopt a model of environmental action, achieve the synergy of all stakeholder activities and manage natural values with a view to ensuring environmental integrity and preserving and enhancing the quality, cleanliness and attractiveness of the destination. Development of integrated and strategic plans of tourism activities is vital for the concept of sustainable tourism to be successfully implemented at the destination level. This has to be done responsibly, taking into consideration the natural values of the destination and the need for environmental protection.

\section{References}

Ahlheim, M., Lehr, U. 20oo. Ordnungspolitik und Treibhauseffekt - Wo bleiben die Bürgerpräferenzen?, Wirtschaftsdienst 4, 80, 249-256.

Ahlheim, M., Lehr, U. 20oo, Ordnungspolitik und Treibhauseffekt - eine Erwiderung, Wirtschaftsdienst $\mathrm{IV} / 2000,80,249-256$.

Atkinson, G. 200o. Measuring Corporate Sustainability. Journal of Environmental Planning and Management 43, 2, 235-252

Bossel, H. (1999) Indicators for Sustainable Development: Theory, Method, Applications. A Report to the Balaton Group, IISD, Canada.

Coccossis, H., Mexa, A., (2004). The challenge of tourism carrying capacity assessment- theory and practice. Ashgate Publishing, Ashgate.

Dredge, D., Moore, S. 1992. A Methodology for the Integration of Tourism in Town Planning, The Journal of Tourism Studies, 8-21.

Farsari, Y., Prastacos, P. 2001. Sustainable tourism indicators for Meditarrean established destinations. Tourism Today 1 (1): 103-121.

Gunn, C. A., (1994) Tourism Planning: Basics, Concepts, Cases, Washington DC, Taylor \& Francis

Hardi, P. and Barg, S. (1997) Measuring Sustainable Development: Review of Current Practice, Occasional Paper N. 17, Industry Canada, Ontario.

Hart, o. (I995) Firms, Contracts, and Financial Structure. Forthcoming, Oxford University Press.

Komppula R. 2014. The role of individual entrepreneurs in the development of competitiveness for a rural tourism destination. Tourism Management, 361-371.

Meadows, D. (1998) Indicators and Information Systems for Sustainable Development. A report to the Balaton Group, The Sustainability Institute. 
Mowforth, M., Munt, I. (1998) Tourism and sustainability: New tourism in the Third World, London, Routledge.

Petersen, L.A. (2010) An Examination of Integrated Rural Tourism Development in the Goris Region of Armenia, Utah State University, Logan, Utah.

Ritchie, J.R.B. (200o). The competitive destination: A sustainability perspective. Wallingford, UK: CABI Publishing.

Ritchie, J.R.B., Crouch, G.I. (2003) The competitive destination: A sustainable tourism perspective, CABI publishing, Oxon, UK.

Sharpley R., Vass A. (2006) Tourism, farming and diversification: An attitudinal study, No. 1040-1052

Spangenberg, J., Bonniot, O. (1998) Sustainability Indicators: A Compass on the Road Towards Sustainability. Paper presented in OECD Expert Workshop on Sustainable Development Indicators, OECD, Paris

Wackernagel, M., Rees, W. (1996) Our Ecological Footprint: Reducing Human Impact on the Earth, Gabriola Island, BC, New Society Publishers.

Wang Y. (2011) Destination marketing E management: Scope, definition and structures, CABI, Wallingford, UK.

Zellmann P., Mayrhofer S. (2015) Die Urlaubsrepublik - Die Zukunft des Tourismus in Österreich, MANZ, Wien 